\title{
Exploring into the New Model Procedure in Translation: Wafting as a Case in Point
}

\author{
Alireza Akbari \\ Foreign Languages Faculty, University of Isfahan \\ PO box 81746-73441, Isfahan, Iran \\ Tel: 98-937-146-5966 E-mail: Dictogloss@gmail.com
}

Received: 22-08- 2013

Accepted: 29-09-2013

doi:10.7575/aiac.ijels.v.1n.2p.18

URL: http://dx.doi.org/10.7575/aiac.ijels.v.1n.2p.18

Published: $31-10-2013$

\begin{abstract}
Choosing the near equivalence for translator is of great concern nowadays. While it seems more commitment has been given to this issue, yet there are still rooms for more attention to innovative methods of Translation Studies in this direction. The idea of wafting procedure in Intermediacy model of translation comes from a book by Alireza Akbari (2011) in which hestates completely how to choose the right equivalence in every situation. This research is an attempt to ascertain whether wafting procedure of Intermediacy model of translation will help the translators to opt for the near equivalents to the intended text. Three kinds of wafting procedure are scrutinized on English-German vocabularies in Intermediacy model of translation. The scrutiny shows that utilizing wafting process in translation will make the translation more natural and easy to understand. The results suggested that wafting procedure can provide translator with opportunities to opt for the right equivalence in this connection.
\end{abstract}

Keywords: equivalence, Translation Studies, wafting procedure, Intermediacy Model of Translation

\section{Introduction}

\subsection{Background of the Translation}

Nowadays, translation has assumed a significant place in the fields such as medicine, engineering, law, and literature. Translation is a means of transferring the correct content of the source language into the target one and vice versa. But, the important note to take into account will be how the translator can transmit the intended information and content in the right direction and how the renderer can create the same feeling of the translated text into the target audience. How can interpreters either simultaneous or consecutive, interpret brilliantly to change the environment and cause to ameliorate the political or theological relations among nations? These are some of the pivotal questions to be taken into account. It should be noted that every translator/ interpreter has his or her own strategies to render. Therefore, one cannot say that the only possible way to translate is to find new method or theories in this regard. To translate correctly, depends first on the nature of the translator or interpreter in which how he or she can deal with every situation. Second, it is better to know some robust techniques of translating in this regard. Many a translator does not know anything about the theories of translation, but he or she can translate like a professional one. Let's face it; translation basically means "crossing the river" or "Üersetzungwissenschaft" in German language, and "la traduzione" in Roman language as well. In this regard, "crossing the river" needs some advanced tools to pass comfortably. These tools can be strategies, theories, and even the procedures of translating. The term of translation has three meanings (1) the science generally, (2) the product which will be called "translation" and (3) the process which will be named "translating". Therefore, Hatim and Munday (2004, p.6) emphasize the "ambit of translation" which includes (1) the process of transferring a written text from source language to target one, conducted by a translator, or translators, in specific socio-cultural context. (2) The written product. Or target text, which results from that process and which functions in the sociocultural context of the target language. And (3) the cognitive, linguistic, visual, cultural and ideological phenomena which are an integral part of phases (1) and (2). Translation Studies (TS) consider the form, the meaning, and reconstructure of the word. Therefore, "form" is completely concrete and "meaning" will be abstract. In fact, translation involves transferring the meaning of the first language to the form of second language by the help of semantic structure (Larson, 1984, p.3). Further, Roger Bell (1999, p.6) expressed that "translation is the replacement of the representation of an equivalent text in second language." As far as we know, language generates lots of vocabularies and different variation of words per se. And it means that translating amongst languages becomes an ordeal works nowadays. To make the long story short, there are lots of cases that arise for the translator in rendering source language into the receptor one. First, the "form" of the words which differs from source and target language, second, the abstract representation of meaning, and third, there are lots of theories, procedures, and strategies of translating the source language into the receptor language via translator.

\subsection{The Statement of the Problem}

Every day, lots of words eliminate from the language. Words that are in some situation will be terribly hard to understand. Words convey the special meaning. And now, how can the renderer deal with this situation in order to 
transfer the exact meaning of the word? This study investigates the strategies of "borrowing" of Vinay and Darbelnet (1958/1995) and then proves that the mentioned strategies cannot be utilized in every field of translation in this regard. Then the author utilizes the other exact term known as "Wafting" process (Akbari, 2011).

\subsection{The Scope of Analysis}

In order to get an exact and good result, this study concentrates on "wafting" process only to make an astringent comparison between English and German words in accordance with Denglish dictionary (2013). The analysis covers all types of "wafting" process in order to get the results of the analysis related to the procedure as well.

\subsection{The Significance of Study}

I anticipate some significance both theoretically and functionally in this regard. From theoretical point of view, this study is utilizable for the learning of the "wafting process" amongst diverse languages especially English, Italian, and Persian and this study also will be useful in translation, particularly in understanding the efficacies of the "wafting process" to procure a good translation. From the functional point of view, this study will be so powerful for those who want to securitize the nature of the intended process of translation to produce an incredible interpretation.

\subsection{Research Question}

To what extent will wafting process of Intermediacy model of translation be effective in modern English-German words?

What types of wafting process are found in translation of German words into English in accordance with Denglish dictionary?

\section{Review of Literature}

\subsection{A Terse Delineation of Borrowing Process}

The concept of "borrowing" process was stated by Vinay and Darbelnet. According to the Vinay and Darbelnet in the "translation study reader" (Venuti, 2000, p.84-91), "a translator can apply any procedures such as borrowing, calque, literal known as direct translation and transposition, modulation, correspondence, and adaptation known as oblique translation." Borrowing is defined as a type of direct rendering in which elements of source language are replaced by receptor language elements. For instance, the Russian words such as "verst" or "pood" and Spanish "tequilas" or "tortillas" which might give a translation, a Russian or Mexican flavor when introduced as borrowing (Vinay and Darbelnet in Venuti, 2008, p.58). Many researchers by their taste classified borrowing into various groups. For example, Hocket and Prasasty (2002, p.16) classified the borrowing process into three groups: loan, pronunciation borrowing, and grammatical borrowing. Molina and Albir (2002, p.520) regiments borrowing into two sorts: (1) pure borrowing and (2) naturalized borrowing. The above-mentioned researchers just look at the surface meaning of the word "borrowing". Therefore, it would be better to ponder deeply and trace some line to make translation universal to be well-ruminatable practically and theoretically. As far as we know the term "borrowing" can create stylistic effects in rendering superficially and does not scrutinize the deep layer of each word. Last but not least, the process of "borrowing" can cause the creation of "false friend or der falsche Freund" and then creates translation ambiguous with complex sense. To clarify the whole subject, this paper scrutinizes borrowing process which causes the creation of false friend in part 3.

Further, I will explain the fundamental issue of the term "Wafting" to solve the intended problem completely. As a matter of fact, the process of borrowing can make a language intricate and hardly understandable.

\subsection{Semantic Overlap between English Borrowed Words, Their Use in German, and the Native German}

After perusing the incorporation of borrowed words into German language, I juxtaposed the meanings of English words, the similar English words as utilized in German, and the equivalent native German words. In this connection, in order to gain some insight into the semantic overlap, Mary Lane (2011, p.22-32) conducted a survey of native German speakers' attitudes, knowledge, and usage of various English loan words in German. The loan words which she investigated would be "Band, Ticket, and Girl". In her survey, she asked if the German utilized these kinds of words into their daily conversation, and do these above-mentioned words carry the primary meaning in English? Then she went through the connotational meaning of these words as well. The results show that, in most cases, the primary meaning is of great importance and secondary meaning or metaphorical meanings are less important. It means that borrowing pays attention to the surface structure of the indented words and deep layer of meaning will not be of great importance.

\subsubsection{Band}

The word of "die Band" in German and the intended word in English have a wider range of meaning in these two languages. In English, band alludes to a musical group, a rubber band or some other means of binding things together, a group of people, or a wedding ring. In German, however, only the surface meaning 'musical group, band' has been borrowed along with the loan Band. Therefore, one should say the near equivalence word to the intended one will be "Gruppe" since it has not been restricted to musical group and then it transfers the exact sense as the word in English. In this direction, her survey shows that $95.2 \%$ of respondents express that they utilize the word of Band as a musical group, even though they might replace it by the word "Gruppe". 


\subsubsection{Ticket}

As Mary Lane said, the word of "ticket" in English and "Ticket" in German are interesting in terms of rendering. She expressed that "There are a multitude of German words that could be translated into English as ticket, such as Fahrkarte and Fahrschein 'railroad ticket', Flugschein 'plane ticket', Eintrittskarte'entrance ticket', and Strafzettel and Strafmandat 'traffic or parking ticket'." Therefore, one might say that that the word Ticket coincides in meaning with the first four of these native German Translations. She then reports that "Eighteen speakers 85.7\% report that they use Ticket, though some of them said that they do not necessarily use it more than the alternatives. Though there is some sense that one might not use Ticket with much older people, it seems to be fairly universally accepted, recognized, and understood." Therefore, it is completely natural to say that only the meaning of "entering pass" will be intended.

\subsubsection{Girl}

The word of "Girl" in English has various meanings but there are a few meanings in German. As Lane stated, none of the respondents utilize the German word Girl, with its primary meaning "FEMALE CHILD". In this connection, none of the respondents ponder that the multitude of meanings of the intended word can be conveyed with the loan word "Girl", particularly the primary meaning as "female child". Lane then expressed that "All twenty-one speakers report that they do not use the English loan Girl 'girl' and that native speakers would not use it to refer to young female children at all, one would always say Mädchen 'girl' or Mädel 'girl'. Mädel is more informal than Mädchen and as will be discussed below, seems to be more acceptable when referring to people who are not young, female children." Last but not least, the word "Girl" has not gained popularity amongst German speakers, however it seems that a few speakers are eager to utilize the intended word, though not with its primary English meaning as "female child". Therefore, one would say that borrowing procedure concentrated on stylistic reason of word meaning and it did not pay attention to the deep layer of word meaning. Therefore, it might not be a powerful procedure in which a renderer relies on.

\section{Methodology}

\subsection{A Complete Expound of "Wafting" Process}

Let us define the word of wafting and explain its difference from "Borrowing" stage of Vinay and Darbelnet. "Waft in Merriam Webster dictionary is defined as: "to move or go lightly on or as if on a buoyant medium." If the audience pays attention to the word of "go lightly", he/ she discerns for which Intermediacy model of translation such a word is utilized. Intermediacy model scrutinizes three rich languages in this direction: Persian, German, and Italian languages. These are the ones with big and brilliant history of communication and interpretation. Therefore, Intermediacy Model is met to utilize the suited word which both carries the sense of the word and the message as well as the code-unit behind the text. Persian, German, and Italian languages are the ones which resist more than the other languages when encountering the strange or eccentric words. German, Persian, and Italian people are likely to use the nativized [naturalized] and local words in speaking and writing. It is completely permissible to pose the question of "what is the difference between wafting and borrowing?" Are they the same and carry the same message in Translation Studies? Let's come back to the main word of "go lightly". Wafting is used by every translator in order to create deep layer of stylistic effect. There are some reasons why a translator wafts words. The strong reason for wafting words is that sometimes people get difficulty in understanding the messages in the translated form. Besides, sometimes people will easily receive the information if it is written in the original form than in translated form. Moreover, sometimes the loan word does not have the translated form or cannot be translated. The common reason for wafting words is prestige. There are three reasons why languages waft from one another. First, there are internal linguistic factors such as word frequency, word intensity. Words that are used less frequently are less stable and more subject to replacement - word obsolescence. Also, a language may waft a word to replace one of pair of homonyms so as to resolve the clash that results from words pronounced alike with different meanings. A second reason is that languages have a constant need for equivalence in domains such as emotions, food, flora, fauna and communication. The third reason is when the old word loses their 'power', waftings are gladly accepted. Borrowing or transference is the process which never lasts in a developed and developing society. It is completely like the process of temporary metaphor (Newmark, 1988, p.107). Whenever such words enter a language with the aid of "Borrowing" process, they never last long. The other important note about the "borrowing' would be that borrowed words live a different life in the borrowing language and it makes back-translation difficult. For instance, some English law terms do not have any counterpart in the Russian language such as covenant (it needs to be transliterated (to specific an obligation is meant, the target language just does not have enough words to express the idea of obligation with a variety of shades of meaning) or gin and tonic clause which an equivalent had to be coined in Russian language. In these two cases borrowing cannot play the main role since it has had the superficial stylistic effects on words. It should be considered that the best way to test the nature of borrowing is back-translation. In the light of this explanation, it is better to say that, "How can we enter some words to our language to carry the essence of the exact meaning and last long?" Whenever an eccentric word enters Persian, German, and Italian societies, most of the people resist accepting such a word and this is the reason of patriotism and the heritage of the intended people. Therefore, there should be a procedure which both conveys the meaning and the sense exactly. When a word creates via "Borrowing" process, most of the literati people utilize this word before they could say Jack Robinson. But the problem is that the age of such a word would be little and cannot be counted. For instance, most of the German people cannot stand using a foreign word in their language and try to homogenize that word. And this is why German is a complete regular language and it always says complete principals for its language. In this process, "Borrowing" will be failed and will not play its role in the right direction. For instance, "coup d'état"Abolishment $\rightarrow$ a sudden violent or illegal seizure of government - has the best equivalents in Persian as "Shuresh 
sazmandehi shode" and "der Staatsstreich" in German. Whenever this word comes to Persian and German society, every one shuns using such a word and he or she refuses to utilize it. It is natural to express that the intended people love to utilize the homogenized words. The renderer should not consider the experts or common people alone. He or she should ponder about decoding ability fairly and completely. Decoding ability in any language involves at least four principal levels: (1) the capacity of children whose vocabulary and cultural experience are limited. (2) The double standard of capacity of new literates, who can decode oral message with facility but whose ability to decode written message is limited. (3) the capacity of average literate adult, who can handle both oral and written messages with relative ease; and (4) the unusually high capacity of specialists (doctors, theologians, philosophers, scientists, etc.), when they are decoding messages within their own areas of specialization (Eugene Nida,1964, p. 156-71). The most sensitive groups in decoding ability will be children and adults. The renderer should translate such words in order not to observe resistance of the intended groups as well. Statistics shows that nativized words can be more impressive than those of foreign words. Therefore, "Wafting" process of Intermediacy Model will be better to render as the generalized method. In "Wafting' process, each foreign word is scrutinized correctly and then lightly enters the intended language. In this connection, "Wafting Nativization" will be noticeable. For instance, "ad hoc formulation" will be rendered as "tashrifate vijeh" or "das Ad-hoc-Formulierung". Statistics shows that people do not resist using such nativized words and accept them as pivotal words of their languages. Intermediacy Model does not preserve local color of ST word and then it pays more attention to "deep nativization" of the words. "Wafting" is a long-term procedure and lasts long in the Persian, German, and Italian societies.

The other point is that how to render proper nouns according to the wafting process of Intermediacy Model. Whenever you look at the subtitles of the films or dubbing process, the speaker utilizing the exact name of that person is preserving the local color of ST. In this connection, Newmark $(1988$, p.81) states that people's first and surnames are transferred, thus preserving their nationality, and assuming that their names have no connotation in the text. This action will be posed one question. What is the role of decoding ability? Intermediacy Model expresses that it'll be drastic to use the nativized names of foreign ones. One of the sensitive groups among decoding ability of Nida will be children. In practice, when the process is based on parallel categories, in which we can speak of structural parallelism, a direct translation may be possible to transpose the SL message element by element into the RL. However, in the RL, the translators should pay attention to notice gaps, which is in RL must be filled by corresponding elements so that the overall impression is the same for the two messages. Wafting, a direct and intense translation process will transfer the original source language by inserting or absorbing the source language word or phrase form into the receptor language such proper nouns, flora, fauna, and technological terms. Proper names play an important role in a literature. In translating proper name for children, it is noticeable to render such words according to their taste. In this respect, children can depict the obvious picture of word and can easily connect themselves to the intended word. For example, "Rihanna" will enter Persian, German, and Italian Languages without any alteration via "Borrowing" process. Now imagine your decoding ability would be a child. How can the renderer convey the exact meaning of a word to a baby in Iran? As a matter of fact, children want to hear the words which they want "Not the words with foreign heritage and weird pronunciation" (Nida, 1964, p.156-71). It is completely natural to say that the renderer cannot convey and transmit the exact sense of that name. Intermediacy Model suggests using the nativized word as "Reihane" instead of "Rihanna". "Reihane" passed the filter of deep layer of wafting process was then nativized elegantly in order to convey the exact sense of the intended word. Decoding abilities are convenient using such term. "Wafting" process would be thoroughly specific and agreeable process to convey the sense of the words exactly.

\subsection{Types of Wafting}

In this regard, this paper divides "wafting procedure" into 3 subcategories to show the intensity and resistancy of the word wafted in language. These subcategories are vehemently pertained to intensity and frequency of the word. It is better to scheme these procedure like this:

\section{Wafting: $\underset{\begin{array}{l}\text { W. Freq } \\ \text { W.Inten }\end{array}}{\longrightarrow}\left\{\begin{array}{l}\text { Partial Wafting } \\ \text { Naturalized Wafting }\end{array}\right.$ \\ Note: $\mathrm{W}$ stands for word \\ Freq stands for frequency \\ Inten stands for intensification \\ 3.2.1 Partial wafting \\ Total Wafting}

Partial wafting is any kind of wafting process in which the intended word wafts partially and carry the main essence of the word according to word frequency. This wafting process preserves partially the local color of source language and it 
is better not to use this procedure in translation because it makes the text artificially translated. For example, artistic in English wafts partially in "artisti" in Persian and it is better to use the word of "honari" to carry the main essence of the word. "Class" in English changes into "kelas" or "il classe" in Italian. This kind of wafting is specially used amongst the experts and specialists.

\subsubsection{Total wafting:}

Total wafting is any kind of wafting process in which the intended word wafts totally and carries the main essence of the word. In this connection, intensity plays the worth character than frequency. This kind of wafting does not preserve the color of source language and that is completely coincided to the target text. In fact, people do not resist utilizing this kind of wafting in their daily conversations and their translations of the various texts.

\subsubsection{Naturalized/ nativized wafting:}

A word can be naturalized wafting when it can be naturalized to fit the spelling rules in the Target Language (TL). Naturalized wafting will be any kind of wafting process in which the intended word wafts partially or totally but naturally transforms the main essence of the intended word. This wafting process applies both frequency and intensity of the word to carry the exact theme of the word. In this direction, naturalized wafting is sometime pertained or inclined to partial wafting and sometimes to total wafting.

\section{Data Analysis}

This chapter is in concerned with the analysis of English words that more express Wafting procedure of Intermediacy model of translation in. At least, the analysis in this chapter is done based on the standard integration and absorbing words elements in German system that supports the existence of wafting procedure in translation.

4.1 Application of "Wafting" in the Translation of "General English words" into Germany in Accordance with Denglish Dictionary (2013)

For further explanation, the analysis below is based on the data related to three classification of wafting procedure applied in the translation of "General English words" into Germany. In all these cases, the author pays special attention to both the deep layer and surface meaning of the intended words.

\subsubsection{Partial wafting}

The table below shows partial wafting found in the data. The only note would be that all of the partial wafts in this section scrutinizes deeply and inspects the frequency and the intensity of the intended words in the German language.

The table below show partial wafting found in the data

Table 1. The process of partial wafting.

\begin{tabular}{|c|c|c|}
\hline Source Language & Target Language & Meaning \\
\hline Alpenglow & das Alpenglühen & $\begin{array}{l}\text { a reddish glow seen on the mountain } \\
\text { tops around sunrise or sunset }\end{array}$ \\
\hline Concertmaster & der Konzertmeister & $\begin{array}{l}\text { the leader of the first violin section } \\
\text { of an orchestra, who often also } \\
\text { serves as assistant conductor }\end{array}$ \\
\hline Degauss & das Gauß & $\begin{array}{l}\text { To demagnetize, neutralize a } \\
\text { magnetic field; the "gauss" is a unit } \\
\text { of measurement of magnetic } \\
\text { induction (symbol G or Gs, replaced } \\
\text { by the Tesla), named for German } \\
\text { mathematician and astronomer Carl } \\
\text { Friedrich Gauss (1777-1855). }\end{array}$ \\
\hline Geiger counter & der Geigerzähler & $\begin{array}{c}\text { Instrument for measuring } \\
\text { radioactivity, named for German } \\
\text { physicist Hans Geiger (1882-1945) }\end{array}$ \\
\hline Glitz & Glitzerig & $\begin{array}{l}\text { "glittering, sparkling" - } \\
\text { gaudiness/gaudy, glittery, } \\
\text { ostentatious(ness) }\end{array}$ \\
\hline Kaput & Kaputt & broken, not working; defeated \\
\hline Kris Kringle & das Christkindl & $\begin{array}{l}\text { "Christ child", an English corruption } \\
\text { of Christkindl, the angel-like figure } \\
\text { who brings gifts to German children } \\
\text { on Christmas Eve; now a synonym } \\
\text { for Santa Claus }\end{array}$ \\
\hline
\end{tabular}




\begin{tabular}{|c|c|c|}
\hline Lederhosen & die Lederhose & leather pants \\
\hline Levi's ${ }^{\circledR}$ & Levi Strauss & $\begin{array}{l}\text { Named after the German-born } \\
\text { inventor of jeans }\end{array}$ \\
\hline Liverwurst & die Leberwurst & $\begin{array}{c}\text { "liver sausage" - sausage containing } \\
\text { ground liver }\end{array}$ \\
\hline Loess & der Löss & a fine-grained, fertile loam \\
\hline Masochism & der Masochismus & $\begin{array}{l}\text { Named for the Austrian novelist } \\
\text { Leopold Ritter von Sacher-Masoch } \\
(1836-1895)\end{array}$ \\
\hline Mergenthaler press & Ottmar Mergenthaler & $\begin{array}{l}\text { Named for the German-born } \\
\text { inventor of the Linotype printing } \\
\text { process }\end{array}$ \\
\hline Schussing & der Schuss & $\begin{array}{c}\text { "shot," a straight run in downhill } \\
\text { skiing }\end{array}$ \\
\hline Schnapps & der Schnaps & $\begin{array}{l}\text { "dram, nip" - Any strong, distilled } \\
\text { alcoholic drink (brandy, whiskey, } \\
\text { vodka, etc.); a strongly flavored } \\
\text { Dutch gin (Hollands) }\end{array}$ \\
\hline
\end{tabular}

As we noted above "Partial wafting" is a kind of procedure in which parts of the words waft. But, the most important note is that partial wafting scrutinizes the deep layer of the words. For instance, a word such as "Masochism" in English has the same equivalent as "Masoxism" in Persian. Most of the translators utilize the phrase "xod-azar" instead of "masoxism" for which the only reason will be "decoding ability". As another example, "concertmaster" as the person who conducts the orchestra of musical band, but in Persian it is better to say "Kondaktor" as the replacement of the intended word as well. In every situation, the renderer should consider the audience or the specific term "decoding ability" in order to transmit the exact meaning of the words. It should be noted surface structure of the words will not be considered, however, it is the deep one which is of great importance. It is the duty of renderer to make a deep structure fix not to observe multi-conceptions of one word. And finally, according to the etymology of the above-mentioned words, they came to English language lightly and diachronically due to the fact that they could depict the exact sense and form of the source language.

\subsubsection{Total wafting}

The next table shows total wafting of words found in the data.

Table 2. The process of total wafting

\begin{tabular}{|c|c|c|}
\hline Source language & Target Language & Meaning \\
\hline angst/Angst & die Angst & $\begin{array}{c}\text { "fear" - in English, a neurotic feeling } \\
\text { of anxiety and depression }\end{array}$ \\
\hline Anschluss & der Anschluss & $\begin{array}{c}\text { annexation" - specifically, the 1938 } \\
\text { annexation of Austria into Nazi } \\
\text { Germany (the Anschluss) }\end{array}$ \\
\hline apple strudel & der Apfelstrudel & $\begin{array}{c}\text { a type of pastry made with thin } \\
\text { layers of dough, rolled up with a } \\
\text { fruit filling; from the German for } \\
\text { "swirl" or "whirlpool" }\end{array}$ \\
\hline Autobahn & die Autobahn & $\begin{array}{c}\text { "freeway" - The German Autobahn } \\
\text { has almost mythical status }\end{array}$ \\
\hline Blitz & der Blitz & $\begin{array}{c}\text { "lightning" - a sudden, } \\
\text { overwhelming attack; a charge in } \\
\text { football; the Nazi attack on England } \\
\text { in WWII }\end{array}$ \\
\hline Blitzkrieg & der Blitzkrieg & $\begin{array}{c}\text { "lightning war" - a rapid-strike war; } \\
\text { Hitler's attack on England in WWII }\end{array}$ \\
\hline coffee klatch (klatch) & der Kaffeeklatsch & $\begin{array}{c}\text { a friendly get-together over coffee } \\
\text { and cake }\end{array}$ \\
\hline Kaffeeklatsch & &
\end{tabular}


IJELS 1 (2):18-26, 2013

\begin{tabular}{|c|c|c|}
\hline Doppelgänger & der Doppelgänger & $\begin{array}{l}\text { "double goer" - a ghostly double, } \\
\text { look-alike, or clone of a person }\end{array}$ \\
\hline Dreck & der Dreck & $\begin{array}{l}\text { "dirt, filth" - in English, trash, } \\
\text { rubbish (from Yiddish/German) }\end{array}$ \\
\hline Ersatz & der Ersatz & $\begin{array}{l}\text { a replacement or substitute, usually } \\
\text { implying inferiority to the original, } \\
\text { such as "ersatz coffee" }\end{array}$ \\
\hline Fahrvergnügen & das Fahrvergnügen & $\begin{array}{l}\text { "driving pleasure" - word made } \\
\text { famous by a VW ad campaign }\end{array}$ \\
\hline Führer & der Führer & $\begin{array}{l}\text { "leader, guide" - a term that still has } \\
\text { Hitler/Nazi connections in English, } \\
\text { more than } 70 \text { years after it first came } \\
\text { into use }\end{array}$ \\
\hline the Gegenschein & der Gegenschein & $\begin{array}{l}\text { "Counter glow" - The "opposition } \\
\text { effect," a diffuse, faint light } \\
\text { sometimes visible almost directly } \\
\text { opposite the sun in the night sky, } \\
\text { thought to be sunlight reflected by } \\
\text { dust particles in the atmosphere. }\end{array}$ \\
\hline Gemütlich & Gemütlich & cordial, cozy, comfortable, warm \\
\hline Gesamtkunstwerk & das Gesamtkunstwerk & $\begin{array}{l}\text { "Comprehensive art work" - In } \\
\text { Richard Wagner's aesthetic theory, } \\
\text { an ideal synthesis of performing arts } \\
\text { (music, drama, staging, etc.) is } \\
\text { forming a kind of total theater, } \\
\text { which equals opera. }\end{array}$ \\
\hline
\end{tabular}

In the process of "total wafting", the renderer transmits the exact word into the target language in order to convey the main essence of the original word. However, it should be noted that in the process of "total wafting" the renderer should pay special attention to the higher and lower incoming of the intended words. To put it in the nutshell, language intensification is pertained to language resistancy. Since the Persian, German, and Italian languages have had the rich history of literature, it is worth finding words to meet the needs of people as well. In all these cases, the renderer should first scrutinize the "decoding ability" of each word in order to convey the same meaning to various ilks of people. It is worth expressing again that the term "wafting" is used for the purpose of deep layer of meaning of the words. It means that for the first stage of rendering, the translator should look closely to the deep structure of the words to convey the deep sense of the words and then with the help of his or her beautification techniques, s/he transfers the deep meaning of the words to the surface one completely. Totally, translation is the change of forms. Whenever a renderer is able to modify the form, s/he can convey the main essence of the text and that is for the reason that the sense per se is translatable but the form will be untranslatable. The only solution will be to reach the deep layer of the words in order to convey the near equivalence of the words. According to Jacobson (1959, p.238), "All cognitive experience and its classification are conveyable in any existing language. Whenever there is deficiency, terminology may be qualified and amplified by loan-words or loan-translations, neologisms or semantic shifts, and finally, by circumlocutions."

\subsubsection{Naturalized Wafting}

The last table shows Naturalized wafting of words found in the data.

Table 3. The process of naturalized wafting

\begin{tabular}{|c|c|c|}
\hline Source Language & Target Language & Meaning \\
\hline Anglicism* & Anglizismen & $\begin{array}{c}\text { Adherence to English costume or } \\
\text { ideas }\end{array}$ \\
\hline soap opera & die Seifenoper & $\begin{array}{c}\text { A television or radio drama serial } \\
\text { dealing daily events of the } \\
\text { same group }\end{array}$ \\
\hline to make sense & Sinn machen & \\
\hline Bath & Der Bad & \\
\hline Which & Welcher & \\
\hline My & Mein & \\
\hline Economy & die Economy & \\
\hline Uncle & Der Onkel & to work \\
\hline Function & Funktionieren & To run slowly \\
\hline to jog & Joggen & \\
\hline Many & Mancher & \\
\hline
\end{tabular}


As stated above, "naturalized wafting" is the best subcategory of the superordinate "wafting" in which it relies on the phonological system of the target language and considers decoding ability more than the former two subcategories. In all these cases that were explained, most of the German speakers do not resist utilizing the intended words since they have covered the deep and surface meaning range. Finally, it is better to say that "wafting" can be used for both stylistic reasons (superficial word meanings) and deep layers of word meanings.

\section{Results and Discussion}

The research questions are as follows: (1) to what extent will "wafting" process of Intermediacy model of translation be effective in modern English words? And (2) what types of "wafting" process are found in translation of German words into English in accordance with Denglish dictionary?

For the first question, one could say that modern English words or totally modern words need to be translated into a modern manner in which every ilk of people ruminates and understands fully in order to convey the main content of the words. In this direction, Intermediacy Model of translation utilizes three kinds of meanings being as follows: (1) the primary meaning, (2) the secondary meaning, and (3) the tertiary meaning. Primary meaning is related to deep layer of meaning which is completely different from "Primary meaning" in linguistics. The latter is relied on the first meaning coming to mind. But the primary meaning of intermediacy model deals with the hidden or deep layer of meaning. The secondary meaning deals with different meanings in different contexts and tertiary meaning is related to the stylistic, expressive, and aesthetic meaning of the intended words. Totally, it can be stated that the "borrowing" procedure of Vinay and Darbelnet pays special attention to tertiary meaning and it is completely natural to see the fact that borrowing leads words to be "Faux Amis" in this regard. It is better to express that in translating words the renderer should be completely/fully aware of the deep layer of meaning of the words. After distinguishing the intended context and the stylistic reason behind the word, s/he chooses the best near equivalent saturating every taste of decoding ability. Therefore, it can be stated that in most of the cases Intermediacy Model of translation will be effective in transferring the main content of the words.

Research question number two deals with subcategories of wafting process. Clearly, partial, total, and nativized wafting can be observed in these inspected words. But the important note is that the translator or interpreter should be on the road of nativized wafting in most of the cases in which he or she wants to saturate the taste of bystanders by his or her equivalent in general. Therefore, choosing the "Naturalized wafting" is of great importance and should be under the condition of ruminating. In this direction, the intended interpreter or translator must scrutinize the frequency and intensity of the word as well. Decoding ability of intermediacy model of translation ties pertains to frequency and intensity of language background. And it is better to say that the frequency of occurrence of words determines the likelihood of their being replaced by wafting process in this regard.

Last but not least, it is important to say that this study has been based on German instances and does not show any corresponding examples related to the Persian and Italian language. It is hoped that some studies would address the case with other languages and would accordingly set out to test the workability of the wafting procedure on a larger number of words in the near future.

\section{Conclusion}

This study wants to investigate the usability of the process of "wafting". Wafting in general is the process of transferring the deep layer of meaning of the words. This study scrutinized three types of wafting: "partial wafting", "total wafting", and "naturalized wafting" in accordance with "Intermediacy model of translation in gray zone" (Akbari, 2011). Partial wafting is any kind of wafting process in which the intended word wafts partially and carries the main essence of the word according to the word frequency. This wafting process preserves partially the local color of source language and it is better not to use this procedure in translation because it makes the text artificially translated. Total wafting is any kind of wafting process in which the intended word wafts totally and carries the main essence of the word. This kind of wafting does not preserve the color of source language and that is completely coincided to the target text. Finally, naturalized/ nativized wafting is the kind of process in which a word can be wafted naturalizingly when it can be naturalized to fit the spelling rules in the Target Language (TL). Naturalized wafting will be any kind of wafting process in which the intended word wafts partially or totally but naturally in order to transform the main essence of the intended word in the target language. This wafting process applies to both frequency and intensity of the word to carry the exact theme of the word. All in all, it should be noted that in doing translation a translator should understand the proper use of words so that s/he will be able to produce good work of translation. Moreover, the translator should understand the cultural background between the source language and the receptor language; hence their translation can be accepted in the receptor language.

\section{References}

Akbari, A. R, (2011). Intermediacy Model of Translation in Gray Zone, Oxford University Press, Unpublished Book.

Bell, Roger T.(1991). Translation and Translating: Theory and Practice. New York: Longman, 6.

Hatim, B. and Munday, J. (2004). Translation, an Advanced Resource Book. London Routledge, 6.

Jacobson, R. (1959). 'On Linguistic Aspects of Translation', in R. Brower (ed.) (1959) On Translation, Cambridge MA: Harvard University Press, 232-9. 
Langenscheidt. (2013). English to Deutsch (Denglish) Dictionary.

Lane, M, (2011). English Loans in German and the Borrowing of Meaning, 22-32.

Larson, Mildred L. (1984). Meaning-Based Translation: A Guide to Cross: Language Equivalences. Lanham: University Press of America, 3.

Molina, L and Albir, A. H. (2002). Translation Technique Revisited: A Dynamic and Functionalist Approach. Spain: Universitat Autonoma da Barcelona, 520.

Newmark, Peter. (1988). Textbook of Translation. U. K: Prentice Hall, 107.

Newmark, Peter. (1988). Textbook of Translation. U. K: Prentice Hall, 81.

Nida, E. A. (1964). Towards a Science of Translating. Leiden: E. J. Brill, 156-171.

Prasasty, Tatari. (2002). An Analysis of English Lexical Borrowing Found in PT. Nestle Indonesia's Catalogue. Medan: Faculty of Letter USU, 16.

Venuti, Lawrence (ed). (2000). The Translation Studies Reader. London: Routledge, 84-91.

Vinay, J. P. and J. Darbelnet (1958/1995). Stylistique comparée du français et de l'anglais. Méthode de traduction, Paris: Didier, trans. and ed. J. C. Sager and M.-J. Hamel (1995) as Comparative Stylistics of French and English: A Methodology for Translation, Amsterdam and Philadelphia: John Benjamins, 58.

Webster, M. (2009). Merriam Webster Collegiate Dictionary

\section{Appendix}

Here is the process of choosing "Near Equivalent" according to Intermediacy Model of Translation

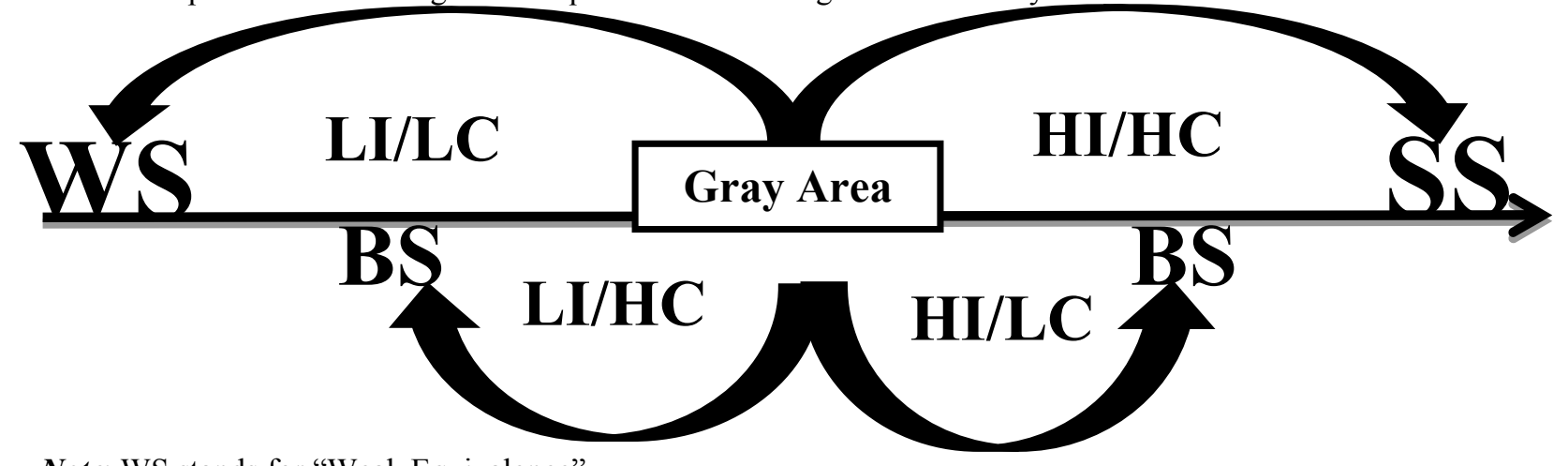

Note: WS stands for "Weak Equivalence"

SS stands for "Strong Equivalence"

BS stands for "Brittle Equivalence"

HI stands for "High Intensity"

HC stands for "High Consequences"

LI stands for "Low Intensity"

LC stands for "Low Consequences'

For better understanding, notice to the example of the word "Stupid" below:

Paradigm of "Equivalence" stage

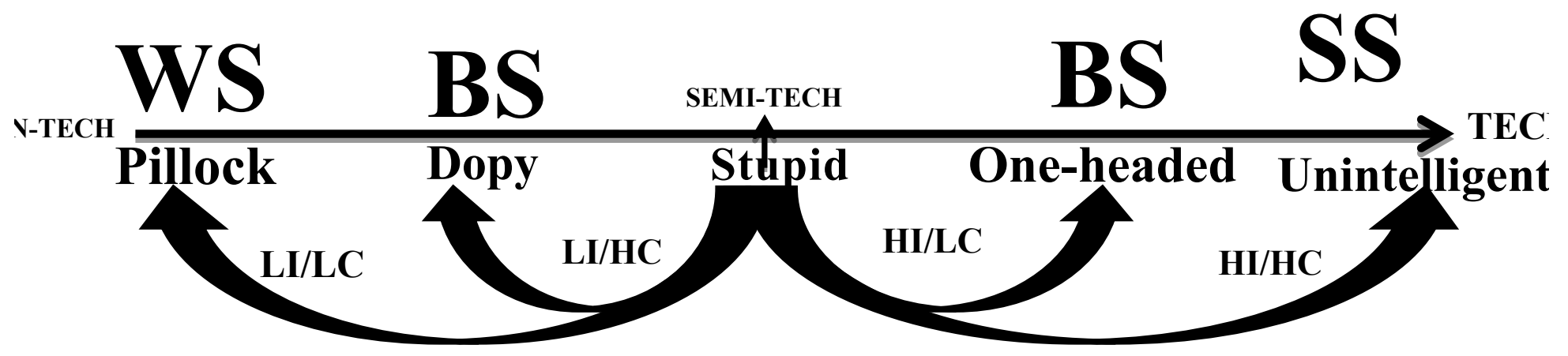

